\title{
Polyoxometalates: Toward new materials
}

\author{
A SRINIVASA RAO, T ARUMUGANATHAN, VADDYPALLY SHIVAIAH and \\ SAMAR K DAS*
}

School of chemistry, University of Hyderabad, Hyderabad 500 046, India

e-mail: skdsc@uohyd.ernet.in

\begin{abstract}
This article describes an account of some of our polyoxometalate (POM)-based research, we have been doing in our laboratory last several years. There are several well-defined POM cluster anions, that are structurally characterized. We have chosen Anderson-type of heteropolyanion $\left[\mathrm{Al}(\mathrm{OH})_{6} \mathrm{Mo}_{6} \mathrm{O}_{18}\right]^{3-}$ and explored its linking propensity in different dimensions using 's', ' $d$ ' and ' $\mathrm{f}$ ' block elements as linkers. We have demonstrated how a lanthanide linker provides a new pathway in forming a two-dimensional linked $\left\{\mathrm{As}_{8} \mathrm{~V}_{14}\right\}$ system $\left[\left\{\mathrm{Ln}\left(\mathrm{H}_{2} \mathrm{O}\right)_{6}\right\}_{2} \mathrm{As}_{8} \mathrm{~V}_{14} \mathrm{O}_{42}\left(\mathrm{SO}_{3}\right)\right]_{\mathrm{n}} \cdot 8 \mathrm{nH}_{2} \mathrm{O}$, that is derived from discrete $\left\{\mathrm{As}_{8} \mathrm{~V}_{14}\right\}$ cluster containing compound $\left(\mathrm{NH}_{4}\right)_{6}\left[\mathrm{As}_{8} \mathrm{~V}_{14} \mathrm{O}_{42}\left(\mathrm{SO}_{3}\right)\right]$. A polyoxometalate compound has been described in which a reduced tungstovanadate-heteropolyanion clusters get linked via capped $\mathrm{V}=\mathrm{O}$ groups into one-dimensional chains. All these systems have already been reported elsewhere. The last portion of this article will be described by a new system $[3-\mathrm{ampH}]_{6}\left[\mathrm{~V}_{10} \mathrm{O}_{28}\right] \cdot 2 \mathrm{H}_{2} \mathrm{O}$ having discrete molecular structure and extended supramolecular structure.
\end{abstract}

Keywords. Polyoxometalates; Anderson-type heteropolyanion; polyoxovanadate; extended structure; supramolecular assembly; new materials.

\section{Introduction}

The research area on polyoxometalate (POM)-based solid state materials fascinates synthetic chemists because of their potential applications in diverse research areas; such as catalysis, electrical, conductivity, medicinal chemistry, and materials science. ${ }^{1}$ Among these, the area of POM-based materials has received special attention due to not only their interesting solid state properties but also their fascinating structural features. ${ }^{2}$ Linking POM cluster anions in one-, two- and three-dimensions results in the construction of extended structures of new metal-oxide based materials from molecular building blocks. These polyoxoanion clusters, which act as building units, have well-defined structures that include Anderson, ${ }^{3}$ Keggin, ${ }^{4}$ paradodecatungstate ${ }^{5}$ anions, heteropolyanion of the type ${ }^{6}\left[\mathrm{UMo}_{12} \mathrm{O}_{42}\right]^{8-}$ and isopolyanions of the types ${ }^{7,8}\left[\mathrm{Mo}_{8} \mathrm{O}_{27}\right]^{6-}$, and $\left[\mathrm{Mo}_{36} \mathrm{O}_{108}(\mathrm{NO})_{4}\left(\mathrm{H}_{2} \mathrm{O}\right)_{6}\right]^{12-}$. We have chosen the Anderson type of heteropolyanion having general formulae $\left[\mathrm{X}^{n+}(\mathrm{OH})_{6} \mathrm{Mo}_{6} \mathrm{O}_{18}\right]^{(6-n)-}$ (protonated form; $\mathrm{X}=$ heteroatom, e.g., $\left.\mathrm{Al}^{3+}, \mathrm{Cr}^{3+}, \mathrm{Cu}^{2+}\right)$ and $\left[\mathrm{X}^{n+}\right.$

*For correspondence
$\left.\mathrm{Mo}_{6} \mathrm{O}_{24}\right]^{(12-n)-}$ (non-protonated form; $\mathrm{X}=$ heteroatom, e.g., $\left.\mathrm{Te}^{5+}, \mathrm{I}^{7+}\right)^{9}$ and we have explored the linking propensity $\left[\mathrm{Al}(\mathrm{OH})_{6} \mathrm{Mo}_{6} \mathrm{O}_{18}\right]^{3-}$ in multi-dimension using an appropriate linker (e.g., a metal cation). We have shown a chain-like extended structure based on an Anderson-type polyanion and a lanthanide cation linker in the compound $\left[\mathrm{La}\left(\mathrm{H}_{2} \mathrm{O}\right)_{7} \mathrm{Al}(\mathrm{OH})_{6} \mathrm{Mo}_{6} \mathrm{O}_{18}\right]_{n} \cdot 4 n \mathrm{H}_{2} \mathrm{O}$ (1). ${ }^{10}$ We succeeded in connecting this versatile building unit (Anderson-type POM anion) with a $\mathrm{Cu}(\mathrm{II})$ complex ion, $\left\{\mathrm{Cu}^{\mathrm{II}}\left(2,2^{\prime} \text {-bipy }\right)\left(\mathrm{H}_{2} \mathrm{O}\right)_{2}\right\}^{2+}$, to form a new type of chain in the compound $\left[\mathrm{Cu}^{\mathrm{II}}\left(2,2^{\prime}\right.\right.$-bipy $)$ $\left.\left(\mathrm{H}_{2} \mathrm{O}\right)_{2} \mathrm{Cl}\right]\left[\mathrm{Cu}^{\mathrm{II}}\left(2,2^{\prime}\right.\right.$-bipy $\left.)\left(\mathrm{H}_{2} \mathrm{O}\right)_{2} \mathrm{Al}(\mathrm{OH})_{6} \mathrm{Mo}_{6} \mathrm{O}_{18}\right]$. $4 \mathrm{H}_{2} \mathrm{O}$ (2). ${ }^{11}$ A three-dimensional coordination polymer, $\mathrm{Na}_{3}\left(\mathrm{H}_{2} \mathrm{O}\right)_{6}\left[\mathrm{Al}(\mathrm{OH})_{6} \mathrm{Mo}_{6} \mathrm{O}_{18}\right] \cdot 2 \mathrm{H}_{2} \mathrm{O}$ (3), was isolated when we cooked an acidified aqueous solution of $\mathrm{AlCl}_{3}$ with sodium molybdate. ${ }^{12,13}$ When we performed reactions between sodium vanadate, sodium tungstate and sodium dithionite in an aqueous ammonium acetate buffer, a one-dimensional heteropoly tungstovanadatecoordination polymer $\left(\mathrm{NH}_{4}\right)_{4.68}\left[\left(\mathrm{~V}^{\mathrm{V}} \mathrm{O}_{4}\right) \mathrm{W}_{8}^{\mathrm{VI}} \mathrm{M}_{4} \mathrm{O}_{36}\left(\mathrm{~V}^{\mathrm{IV}} \mathrm{O}\right)_{2}\right] \cdot 12 \quad \mathrm{H}_{2} \mathrm{O} \quad(\mathrm{M}=$ $\left.0.71 \mathrm{~V}^{\mathrm{IV}}+0.29 \mathrm{~W}^{\mathrm{VI}}\right)$ (4) is formed. ${ }^{14} \mathrm{We}$ have also explored the linking propensity of the sulfite encapsulated polyoxovanadate (POV) anion, $\left[\mathrm{As}_{8} \mathrm{~V}_{14} \mathrm{O}_{42}\left(\mathrm{SO}_{3}\right)\right]^{6-}$ with aqua-lanthanide-aqua complex cations $\left[\mathrm{Ln}\left(\mathrm{H}_{2} \mathrm{O}\right)_{6}\right]^{3+}$ in a controlled wet synthesis resulting in a series of organic free metal-oxide based 
materials $\left[\left\{\mathrm{Ln}\left(\mathrm{H}_{2} \mathrm{O}\right)_{6}\right\}_{2} \mathrm{As}_{8} \mathrm{~V}_{14} \mathrm{O}_{42}\left(\mathrm{SO}_{3}\right)\right] \cdot 8 \mathrm{H}_{2} \mathrm{O} ; \mathrm{Ln}=$ $\mathrm{La}^{3+}(\mathbf{5}), \mathrm{Sm}^{3+}(\mathbf{6})$, and $\mathrm{Ce}^{3+}(\mathbf{7}) .{ }^{15}$

$$
\begin{aligned}
& {\left[\mathrm{La}\left(\mathrm{H}_{2} \mathrm{O}\right)_{7} \mathrm{Al}(\mathrm{OH})_{6} \mathrm{Mo}_{6} \mathrm{O}_{18}\right]_{\mathrm{n}} \cdot 4 \mathrm{nH}_{2} \mathrm{O}} \\
& {\left[\mathrm{Cu}^{\mathrm{II}}\left(2,2^{\prime}-\text { bipy }\right)\left(\mathrm{H}_{2} \mathrm{O}\right)_{2} \mathrm{Cl}\right]} \\
& \times\left[\mathrm{Cu}^{\mathrm{II}}\left(2,2^{\prime}-\text { bipy }\right)\left(\mathrm{H}_{2} \mathrm{O}\right)_{2} \mathrm{Al}(\mathrm{OH})_{6} \mathrm{Mo}_{6} \mathrm{O}_{18}\right] \\
& \cdot 4 \mathrm{H}_{2} \mathrm{O} \\
& \mathrm{Na}_{3}\left(\mathrm{H}_{2} \mathrm{O}\right)_{6}\left[\mathrm{Al}(\mathrm{OH})_{6} \mathrm{Mo}_{6} \mathrm{O}_{18}\right] \cdot 2 \mathrm{H}_{2} \mathrm{O} \\
& \left(\mathrm{NH}_{4}\right)_{4.68}\left[\left(\mathrm{~V}_{4}^{\mathrm{VO}}\right) \mathrm{W}_{8}^{\mathrm{VI}} \mathrm{M}_{4} \mathrm{O}_{36}\left(\mathrm{~V}^{\mathrm{IV}} \mathrm{O}\right)_{2}\right] \\
& \cdot 12 \mathrm{H}_{2} \mathrm{O}\left(\mathrm{M}=0.71 \mathrm{~V}^{\mathrm{IV}}+0.29 \mathrm{~W}^{\mathrm{VI}}\right) \\
& {\left[\left\{\mathrm{Ln}\left(\mathrm{H}_{2} \mathrm{O}\right)_{6}\right\}_{2} \mathrm{As}_{8} \mathrm{~V}_{14} \mathrm{O}_{42}\left(\mathrm{SO}_{3}\right)\right]} \\
& \cdot 8 \mathrm{H}_{2} \mathrm{O} ; \mathrm{Ln}=\mathrm{La}^{3+}(\mathbf{5}), \mathrm{Sm}^{3+}(\mathbf{6}), \text { and } \mathrm{Ce}^{3+}(\mathbf{7}) .
\end{aligned}
$$

In this article, we have narrated an account of above mentioned seven compounds (1-7), that are already reported in last several years from our laboratory, ${ }^{10-15}$ in terms of their syntheses and solid state structures. Finally, a new POV system $[3-\mathrm{ampH}]_{6}\left[\mathrm{~V}_{10} \mathrm{O}_{28}\right] \cdot 2 \mathrm{H}_{2} \mathrm{O}$ (8) would be described emphasizing the supramolecular interactions between the isopolyanion $\left[\mathrm{V}_{10} \mathrm{O}_{28}\right]^{6-}$ and surrounding organic cations $[3-\mathrm{ampH}]^{1+}$.

\section{Experimental}

\subsection{Synthesis of 1-7}

We described the synthetic procedures for compounds 1-7 earlier. $^{10-15}$

2.1a Synthesis of $[3-a m p H]_{6}\left[V_{10} \mathrm{O}_{28}\right] \cdot 2 \mathrm{H}_{2} \mathrm{O}$ (8): Sodium meta-vanadate $(1.00 \mathrm{~g}, 0.82 \mathrm{mmol})$ was dissolved in $50 \mathrm{ml}$ of hot deionized water and its $\mathrm{pH}$ was adjusted to 2.00 by adding dil. $\mathrm{HCl}$; to this solution were added $20 \mathrm{ml}$ of aqueous solution of $\mathrm{Zn}\left(\mathrm{NO}_{3}\right)_{2}$. $5 \mathrm{H}_{2} \mathrm{O}(0.5 \mathrm{~g}, 1.8 \mathrm{mmol})$ and 3-Amino pyridine $(0.3 \mathrm{~g}$, $2.9 \mathrm{mmol})$. The reaction mixture was then stirred for $5 \mathrm{~h}$ and little turbidity, appeared, was removed by filtration. The resulting filtrate was kept for crystallization at room temperature. Block-type orange coloured-crystals were found in the solution after 10 days. Yield: $0.46 \mathrm{~g}$ (\% based on Mo) Analysis: Calc. for $\mathrm{C}_{30} \mathrm{H}_{46} \mathrm{~N}_{12} \mathrm{O}_{30} \mathrm{~V}_{10}$ : C, 23.04; H, 2.96; N, 10.74\%. Found: C, 23.10; H, 2.89; N, 10.95\%. IR (KBr pellet): 3335, 3229, 3057, 2085, $1624,1560,1485,1398,1332,1280,1072,968,885$, $829,679,584 \mathrm{~cm}^{-1}$.

\subsection{Physical measurements}

All the chemicals were received as reagent grade and used without any further purification. IR spectra were recorded by using $\mathrm{KBr}$ pellet on a JASCO-5300 FTIR spectrophotometer. The elemental analysis data were obtained with Flash 1112 SERIES EA analyzer. Thermogravimetric analysis was carried out on a STA 409 PC analyzer, under the flow of nitrogen gas.

\section{$2.3 X$-ray crystal structure determination}

The crystallographic data for compound 1-8 has been collected at $293 \mathrm{~K}$ on Bruker SMART APEX $\mathrm{CCD}$, area detector system $[\lambda(\mathrm{Mo} \mathrm{K} \alpha)=0.7103 \AA]$, graphite monochromator, 2400 frames were recorded with an $\omega$ scan width of $0.3^{\circ}$, each for $10 \mathrm{~s}$, crystal-detector distance $60 \mathrm{~mm}$, collimator $0.5 \mathrm{~mm}$. Data reduction by SAINTPLUS, ${ }^{16}$ absorption correction using an empirical method SADABS, ${ }^{17}$ structure solution using SHELXS-97, ${ }^{18}$ and refined using SHELXL-97. ${ }^{19}$ All non-hydrogen atoms were refined anisotropically. The crystallographic details for compounds 1-7 have been described elsewhere. ${ }^{10-15}$ CCDC 761892 contains the supplementary crystallographic data for compound $\mathbf{8}$. This can be obtained free of charge on application to the Director, CCDC, 12 Union Road, Cambridge CB21EZ, UK (fax: +44 1223 336 033; e-mail: deposit@ccdc.cam.ac.uk or www: http://www.ccdc.cam.ac.uk).

\section{Results and discussion}

\section{$3.1\left[\mathrm{La}\left(\mathrm{H}_{2} \mathrm{O}\right)_{7} \mathrm{Al}(\mathrm{OH})_{6} \mathrm{Mo}_{6} \mathrm{O}_{18}\right]_{n} \cdot 4 \mathrm{nH}_{2} \mathrm{O}(\mathbf{1})$}

Compound 1 was synthesized by dissolving $\mathrm{La}\left(\mathrm{NO}_{3}\right)_{3} \cdot 6 \mathrm{H}_{2} \mathrm{O}$ in an acidic aqueous medium followed by the addition of $\mathrm{CH}_{3} \mathrm{COOH}, \mathrm{Na}_{2} \mathrm{MoO}_{4} \cdot 2 \mathrm{H}_{2} \mathrm{O}$ and $\mathrm{AlCl}_{3} \cdot 6 \mathrm{H}_{2} \mathrm{O}$. The formation of the Anderson anion $\left[\mathrm{Al}(\mathrm{OH})_{6} \mathrm{Mo}_{6} \mathrm{O}_{18}\right]^{3-}$ is shown in equation 1.

$$
\mathrm{Al}^{3+}+6 \mathrm{MoO}_{4}^{2-}+6 \mathrm{H}^{+} \rightarrow\left[\mathrm{Al}(\mathrm{OH})_{6} \mathrm{Mo}_{6} \mathrm{O}_{18}\right]^{3-}
$$

This anion reacts with lanthanum cation $\mathrm{La}^{3+}$ available in the reaction medium leading to the isolation of one-dimensional coordination polymer $\left[\mathrm{La}\left(\mathrm{H}_{2} \mathrm{O}\right)_{7} \mathrm{Al}(\mathrm{OH})_{6} \mathrm{Mo}_{6} \mathrm{O}_{18}\right]_{\mathrm{n}} \cdot 4 \mathrm{nH}_{2} \mathrm{O}$ (1). The crystal structure of $\mathbf{1}$ is formed by Anderson-type anions $\left[\mathrm{Al}(\mathrm{OH})_{6} \mathrm{Mo}_{6} \mathrm{O}_{18}\right]^{3-}$ linked by $\mathrm{La}^{3+}$ ions to yield a polymer chain running parallel to the crystallographic $b$ axis (figure 1). The structure of the Anderson anion 


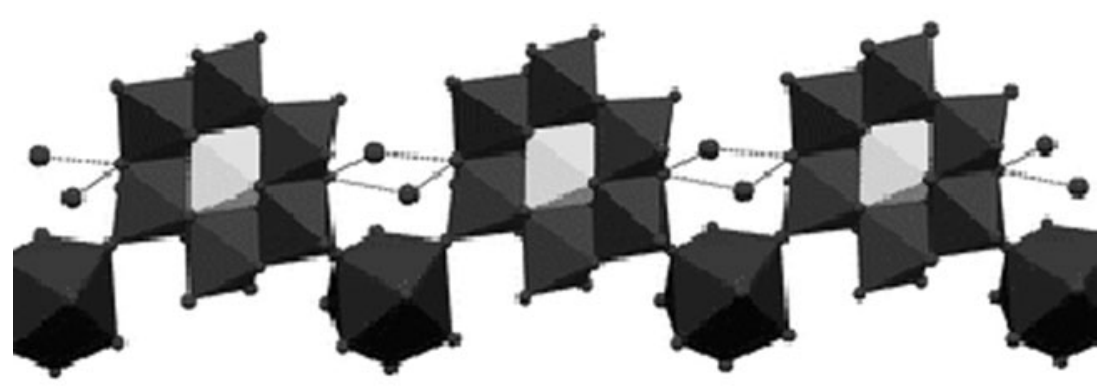

Figure 1. Polyhedral representation of the 1D 'zig-zag' chain, consisting of Anderson-type heteropolyanion and aqua-lanthanum complex cation, running parallel to the crystallographic $b$ axis.

$\left[\mathrm{Al}(\mathrm{OH})_{6} \mathrm{Mo}_{6} \mathrm{O}_{18}\right]^{3-}$ in $\mathbf{1}$ is similar to the structures reported for other Anderson-type anions. ${ }^{20}$ This consists of seven edge-shared-octahedra, six of which are Mo-octahedra arranged hexagonally around the central octahedron containing hetero metal ion, which is $\mathrm{Al}^{3+}$ in the present case. In the crystal structure of $\mathbf{1}$, molybdenum-oxygen distances as expected are divided into four groups: molybdenum-terminal oxygen, $1.68-1.73 \AA$; molybdenum-oxygen linked to lanthanum, $1.72 \AA$; molybdenum-bridging oxygen, $1.88-$ $1.99 \AA$; molybdenum-internal oxygen common to two molybdenum atoms and an aluminum atom, 2.26$2.33 \AA$.

Along the polymer chain, the Anderson anion coordinates to two lanthanum(III) ions through the terminal oxygen atoms (figure 1) of two non-adjacent $\mathrm{MoO}_{6}$ octahedra. In the chain, lanthanum(III) has a coordination number of nine and is in the centre of a tricappedtrigonal prism (figure 1) formed by two terminal oxygen atoms from two $\left[\mathrm{Al}(\mathrm{OH})_{6} \mathrm{Mo}_{6} \mathrm{O}_{18}\right]^{3-}$ units (average $\mathrm{La}-\mathrm{O} 2.604 \AA$ ) and by seven water molecules (average $\mathrm{La}-\mathrm{OH}_{2} 2.546 \AA$ ).

Along the chain the lanthanum ions are wellseparated, with lanthanum-lanthanum distances longer than $11 \AA$ (figure 1).

We have also succeeded to connect this versatile building unit $\left[\mathrm{Al}(\mathrm{OH})_{6} \mathrm{Mo}_{6} \mathrm{O}_{18}\right]^{3-}$ by a transition metal complex $\left[\mathrm{Cu}^{\mathrm{II}}\left(2,2^{\prime} \text {-bipy }\right)\left(\mathrm{H}_{2} \mathrm{O}\right)_{2}\right]^{2+}$ to form a new type of chains in compound $\left[\mathrm{Cu}^{\mathrm{II}}\left(2,2^{\prime}\right.\right.$-bipy $)\left(\mathrm{H}_{2} \mathrm{O}\right)_{2}$ $\mathrm{Cl}]\left[\mathrm{Cu}^{\mathrm{II}}\left(2,2^{\prime}\right.\right.$-bipy $\left.)\left(\mathrm{H}_{2} \mathrm{O}\right)_{2} \mathrm{Al}(\mathrm{OH})_{6} \mathrm{Mo}_{6} \mathrm{O}_{18}\right] \cdot 4 \mathrm{H}_{2} \mathrm{O}$ (2). Compound 2 was synthesized from an aqueous solution of $\mathrm{AlCl}_{3} \cdot 6 \mathrm{H}_{2} \mathrm{O}, \mathrm{Na}_{2} \mathrm{MoO}_{4} \cdot 2 \mathrm{H}_{2} \mathrm{O}$ and $\mathrm{CH}_{3} \mathrm{COOH}$. The reaction mixture was subsequently treated with $2,2^{\prime}$ bipyridine dissolved in a mixture of water and methanol and $\mathrm{Cu}\left(\mathrm{NO}_{3}\right)_{2} \cdot 2 \mathrm{H}_{2} \mathrm{O}$ followed by the addition conc. $\mathrm{HCl}(\mathrm{pH}$ 2.6). The crystal of compound $\mathbf{2}$ is composed of a chain like arrangement of formula $\left[\mathrm{Cu}^{\mathrm{II}}\left(2,2^{\prime}\right.\right.$-bipy $)$
$\left.\left(\mathrm{H}_{2} \mathrm{O}\right)_{2} \mathrm{Al}(\mathrm{OH})_{6} \mathrm{Mo}_{6} \mathrm{O}_{18}\right]_{n}^{n-}$ (as anions), chloro-copper complexes, $\left[\mathrm{Cu}^{\mathrm{II}}\left(2,2^{\prime} \text {-bipy }\right)\left(\mathrm{H}_{2} \mathrm{O}\right)_{2} \mathrm{Cl}\right]_{n}^{\mathrm{n}+}$ (as cations), and some lattice water molecules. The chain is formed by Anderson anions, $\left[\mathrm{Al}(\mathrm{OH})_{6} \mathrm{Mo}_{6} \mathrm{O}_{18}\right]^{3-}$, linked to $\left[\mathrm{Cu}^{\mathrm{II}}\left(2,2^{\prime} \text {-bipy }\right)\left(\mathrm{H}_{2} \mathrm{O}\right)_{2}\right]^{2+}$ complexes as shown in figure 2 .

The chloro-complex cation $\left[\mathrm{Cu}^{\mathrm{II}}\left(2,2^{\prime}\right.\right.$-bipy $)$ $\left.\left(\mathrm{H}_{2} \mathrm{O}\right)_{2} \mathrm{Cl}\right]^{1+}$ is associated with the chain via O-H. . $\mathrm{Cl}$ hydrogen bonding interactions. Interestingly, two chloro-copper complex cations interact with one Anderson anion (alternatively in the chain) instead of each Anderson anion as shown in figure 2, right.

We have seen that ' $S$ ' block metal cation (for example, $\mathrm{Na}^{+}$ion) can also serve as a potential linker to assemble Anderson-type heteropolyanions. A threedimensional coordination polymer containing compound, $\mathrm{Na}_{3}\left(\mathrm{H}_{2} \mathrm{O}\right)_{6}\left[\mathrm{Al}(\mathrm{OH})_{6} \mathrm{Mo}_{6} \mathrm{O}_{18}\right] \cdot 2 \mathrm{H}_{2} \mathrm{O}$ (3), has been isolated when we cooked an acidified aqueous solution of $\mathrm{AlCl}_{3}$ with sodium molybdate. ${ }^{12,13}$ The basis for the formation of this coordination polymer is the coordination of Anderson anion $\left[\mathrm{Al}(\mathrm{OH})_{6} \mathrm{Mo}_{6} \mathrm{O}_{18}\right]^{3-}$ to the sodium cation via $\mathrm{Mo}=\mathrm{O}$ terminal oxygen atoms as shown in figure 3 .

Three-dimensional framework having 'sinuous' channels (figure $4 \mathrm{a}$ ), observed crystallographically, is constructed by the Anderson-type of anions sharing sodium cations resulting in a two-dimensional layer (figure 4b). These layers are laterally linked by sodiumwater chains running in between these layers through the coordination of $\mathrm{Mo}=\mathrm{O}$ terminal oxygen atoms of Anderson anions leading to the three-dimensional structure. The resulting network accommodates guest water molecules in its ' $\mathrm{S}$ '-shaped channels, that are occupied by lattice/solvent water molecules (figure 4a). TGA performed on 3 showed a sharp weight loss $(8.5 \%)$ at $\sim 50^{\circ} \mathrm{C}$, and this corresponded to the loss of 5.7 water molecules per formula unit. Then, the lower hydrate 

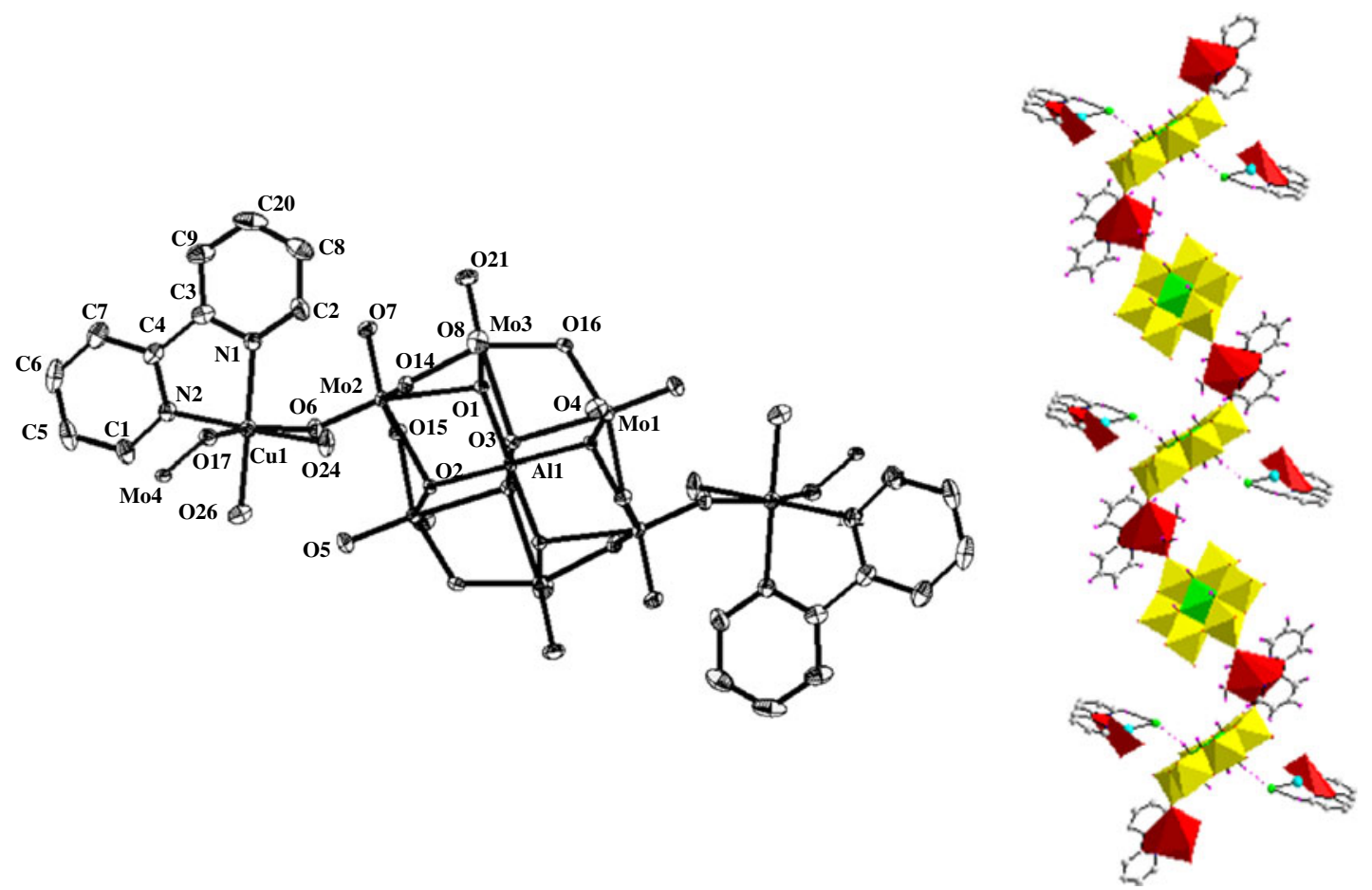

Figure 2. Left: Coordination of an Anderson anion via terminal oxygen atoms on molybdenum to $\mathrm{Cu}$ (bipy) $\left(\mathrm{H}_{2} \mathrm{O}\right)_{2}^{2+}$ complex fragments in compound $\left[\mathrm{Cu}^{\mathrm{II}}\left(2,2^{\prime}\right.\right.$-bipy $\left.)\left(\mathrm{H}_{2} \mathrm{O}\right)_{2} \mathrm{Cl}\right]\left[\mathrm{Cu}^{\mathrm{II}}\left(2,2^{\prime}\right.\right.$-bipy $)$ $\left.\left(\mathrm{H}_{2} \mathrm{O}\right)_{2} \mathrm{Al}(\mathrm{OH})_{6} \mathrm{Mo}_{6} \mathrm{O}_{18}\right] \cdot 4 \mathrm{H}_{2} \mathrm{O}$. Right: the structure of $\left[\mathrm{Cu}^{\mathrm{II}}\left(2,2^{\prime}\right.\right.$-bipy $\left.)\left(\mathrm{H}_{2} \mathrm{O}\right)_{2} \mathrm{Cl}\right]\left[\mathrm{Cu}^{\mathrm{II}}\left(2,2^{\prime}\right.\right.$-bipy $)$ $\left.\left(\mathrm{H}_{2} \mathrm{O}\right)_{2} \mathrm{Al}(\mathrm{OH})_{6} \mathrm{Mo}_{6} \mathrm{O}_{18}\right]$ showing a chain-like array of $\left\{\mathrm{Al}(\mathrm{OH})_{6} \mathrm{Mo}_{6} \mathrm{O}_{18}\right\}^{3-}$ cluster anions interconnected through $\left\{\mathrm{Cu}^{\mathrm{II}} \text { (bipy) }\left(\mathrm{H}_{2} \mathrm{O}\right)_{2}\right\}^{2+}$ bridging copper complex fragments. Two chloro-copper complexes are hydrogen bonded, alternatively, to only one type of Anderson anion in the chain. The Anderson cluster anion is shown in polyhedral representation.

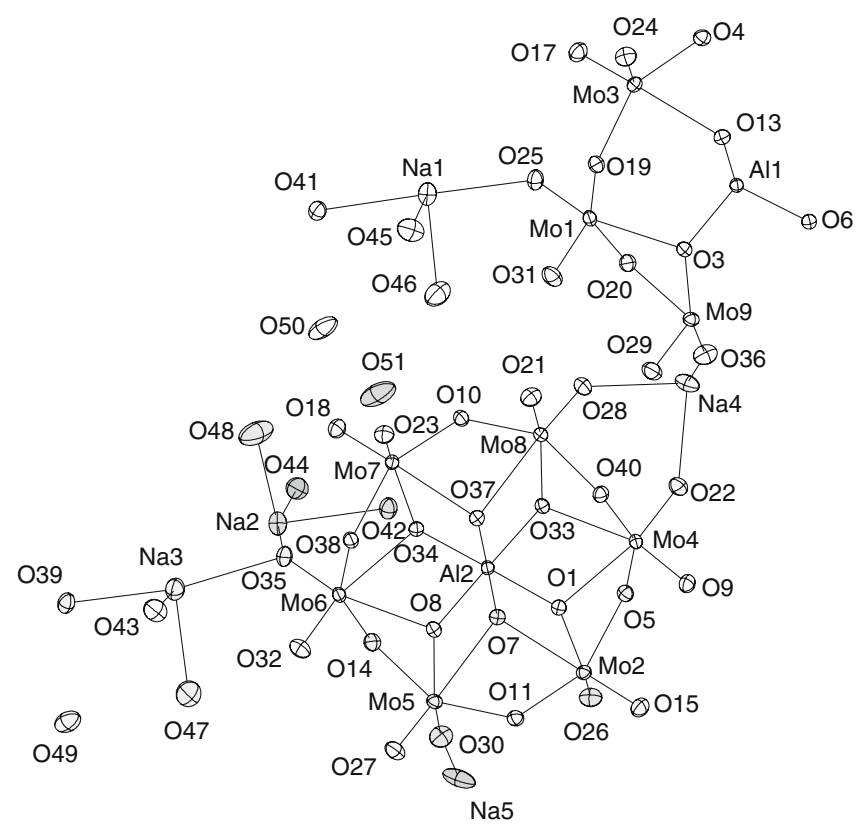

Figure 3. Asymmetric unit (as 1.5 molecules) in $\mathrm{Na}_{3}\left(\mathrm{H}_{2} \mathrm{O}\right)_{6}\left[\mathrm{Al}(\mathrm{OH})_{6} \mathrm{Mo}_{6} \mathrm{O}_{18}\right] \cdot 2 \mathrm{H}_{2} \mathrm{O}(3)$. Sodium coordination of the Anderson anion via terminal oxygen atoms on molybdenum is shown. Thermal ellipsoids at $50 \%$ probability (reproduced from reference 13). remained stable up to $180^{\circ} \mathrm{C}$. When the sample of $\mathbf{3}$ was heated for $2 \mathrm{~h}$ at $125^{\circ} \mathrm{C}$, it removes quantitatively six water molecules. This supports the formulation of the desolvated compound as $\mathrm{Na}_{3}\left(\mathrm{H}_{2} \mathrm{O}\right)_{2}\left[\mathrm{Al}(\mathrm{OH})_{6} \mathrm{Mo}_{6} \mathrm{O}_{18}\right]$. This is in agreement with the elemental analyses. Anal. Found (calcd): Na, 6.35 (6.28); H, 1.05 (0.92). This result is consistent with the first weight loss in the TGA curve corresponding to two solvent and four coordinated water molecules.

Thus, we have discussed a versatile POM cluster anion, $\left[\mathrm{Al}(\mathrm{OH})_{6} \mathrm{Mo}_{6} \mathrm{O}_{18}\right]^{3-}$ that can be used as a successful building unit for the formation of dimensional structures of versatile topologies depending on the linker used. We worked also on polyoxovanadate (POV) systems of extended structures. When we heat an aqueous solution of $\mathrm{Na}_{2} \mathrm{WO}_{4} \cdot 2 \mathrm{H}_{2} \mathrm{O}$ with ammonium acetate buffer $(\mathrm{pH}=4)$, sodium vanadate and sodium dithionite at around $95-100^{\circ} \mathrm{C}$, the filtrate of this reaction mixture, on standing at room temperature for $48 \mathrm{~h}$, affords deep green needle-shaped crystals of $\left(\mathrm{NH}_{4}\right)_{4 \cdot 68}\left[\left(\mathrm{~V}^{\mathrm{V}} \mathrm{O}_{4}\right) \mathrm{W}_{8}^{\mathrm{VI}} \mathrm{M}_{4} \mathrm{O}_{36}\left(\mathrm{~V}^{\mathrm{IV}} \mathrm{O}\right)_{2}\right] \cdot 12 \mathrm{H}_{2} \mathrm{O}$ $\left(\mathrm{M}=0.71 \mathrm{~V}^{\mathrm{IV}}+0.29 \mathrm{~W}^{\mathrm{VI}}\right)(\mathbf{4}) .{ }^{14}$ The crystal structure of $\mathbf{4}$ shows the abundance of reduced capped 
(a)

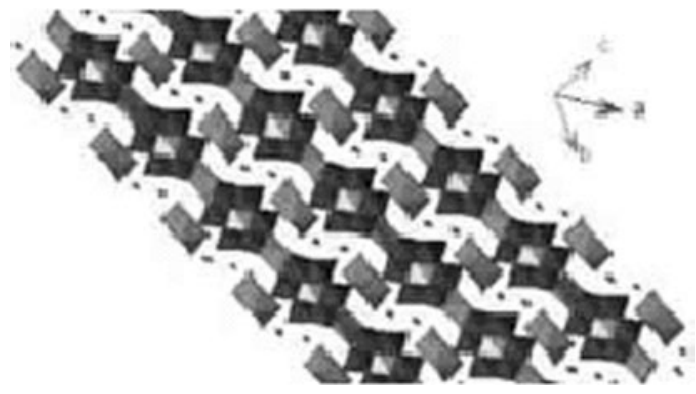

(b)

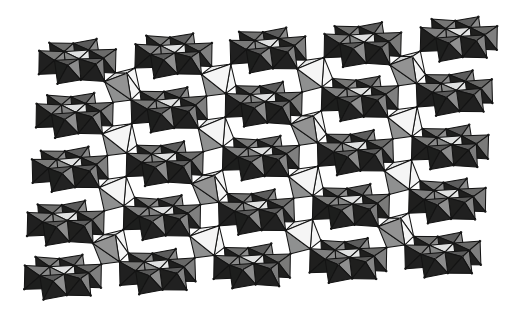

Figure 4. (a) View of the 'sinuous' channels occupied by the guest lattice water molecules in a three-dimensional polymer framework of $\mathrm{Na}_{3}\left(\mathrm{H}_{2} \mathrm{O}\right)_{6}\left[\mathrm{Al}(\mathrm{OH})_{6} \mathrm{Mo}_{6} \mathrm{O}_{18}\right] \cdot 2 \mathrm{H}_{2} \mathrm{O}(3)$. (b) Layer-type of network formed by sodium octahedra and Anderson anions.
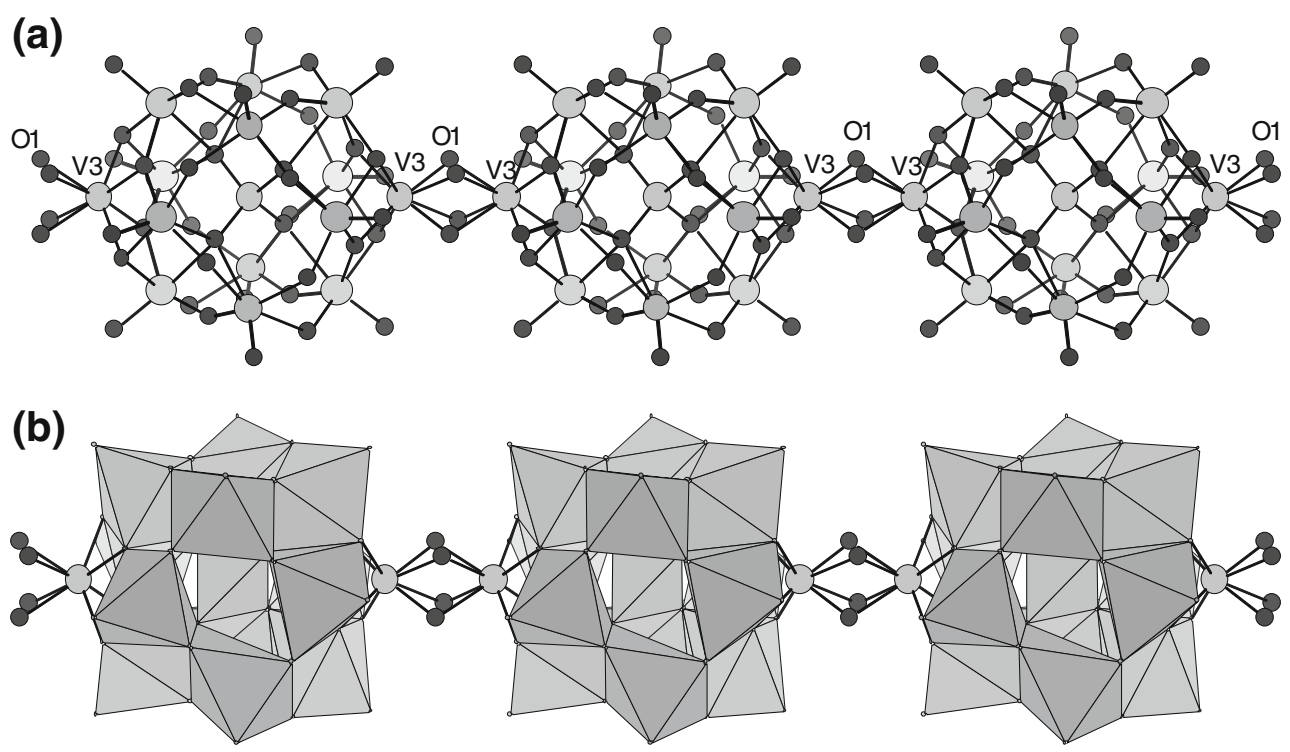

Figure 5. (a) Ball and stick representation of the chain (formed via $\mathrm{V}-\mathrm{O}-\mathrm{V}$ bonds) consisting of reduced capped Keggin fragments running parallel to the crystallographic $c$ axis. The oxygen atom, involved in linking, is disordered over two positions, (b) polyhedral representation of the chain.

Keggin type units $\left[\left(\mathrm{V}^{\mathrm{V}} \mathrm{O}_{4}\right) \mathrm{W}_{8}^{\mathrm{VI}} \mathrm{M}_{4} \mathrm{O}_{36}\left(\mathrm{~V}^{\mathrm{IV}} \mathrm{O}\right)_{2}\right]^{4.68-}$ $\left(\mathrm{M}=0.71 \mathrm{~V}^{\mathrm{IV}}+0.29 \mathrm{~W}^{\mathrm{VI}}\right)$, that are connected by $\left(\mu_{2}-\mathrm{O}\right)_{2}$ oxygen atoms resulting in one-dimensional chains running along crystallographic $c$-axis (figure 5). The structure of the building unit of the chain in 4, $\left[\left(\mathrm{V}^{\mathrm{V}} \mathrm{O}_{4}\right) \mathrm{W}_{8}^{\mathrm{VI}} \mathrm{M}_{4} \mathrm{O}_{36}\left(\mathrm{~V}^{\mathrm{IV}} \mathrm{O}\right)_{2}\right]^{4.68-}$ is shown in figure 6 , which can be described as the derivative of $\left[\left(\mathrm{V}^{\mathrm{V}} \mathrm{O}_{4}\right) \mathrm{W}_{12}^{\mathrm{VI}} \mathrm{O}_{36}\right]^{3-}$ with the replacement of four $\mathrm{W}^{\mathrm{VI}}$ centers by four $\mathrm{M}$ centers, where each of the $\mathrm{M}$ positions is occupied by $71 \%$ of $\mathrm{V}^{\mathrm{IV}}$ and $29 \%$ of $\mathrm{W}^{\mathrm{VI}}$ (V(2) and $\mathrm{W}(3)$, respectively, in the crystal structure of 4), resulting in reduced tungstovanadate Keggin $\left[\left(\mathrm{V}^{\mathrm{V}} \mathrm{O}_{4}\right) \mathrm{W}_{8}^{\mathrm{VI}} \mathrm{M}_{4} \mathrm{O}_{36}\right]^{8.68-}$. This nucleophilic hypothetical species undergo capping by two $\left\{\mathrm{V}^{\mathrm{IV}} \mathrm{O}\right\}^{2+}$ ions from opposite sides along crystallographic $c$-axis to form the basic building unit (figure $6 a$ and $b$ ) of the chain in 4. As shown in figure 5, the linking region is formed by four $\mathrm{V}(3)-\mathrm{O}(1)-\mathrm{V}(3)$ bonds. This is because the atom $\mathrm{O}(1)$ is disordered, under occupied to $50 \%$. Therefore, the linking is actually made by two V-O$\mathrm{V}$ bonds. To the best of our knowledge, this is the first coordination polymer based on tungstovanadate Keggin units. The bond valence sum calculations indicate the presence of all tungsten atoms in +6 oxidation state (as expected), all vanadium atoms (except central tetrahedral vanadium) in +4 oxidation state and the central vanadium in the +5 oxidation state.

In the area of extended POV systems, we have chosen a well-studied sulfite anion encapsulated POV cluster $\left[\mathrm{As}_{8} \mathrm{~V}_{14} \mathrm{O}_{42}\left(\mathrm{SO}_{3}\right)\right]^{6-}$ as a building block and explored 
(a)

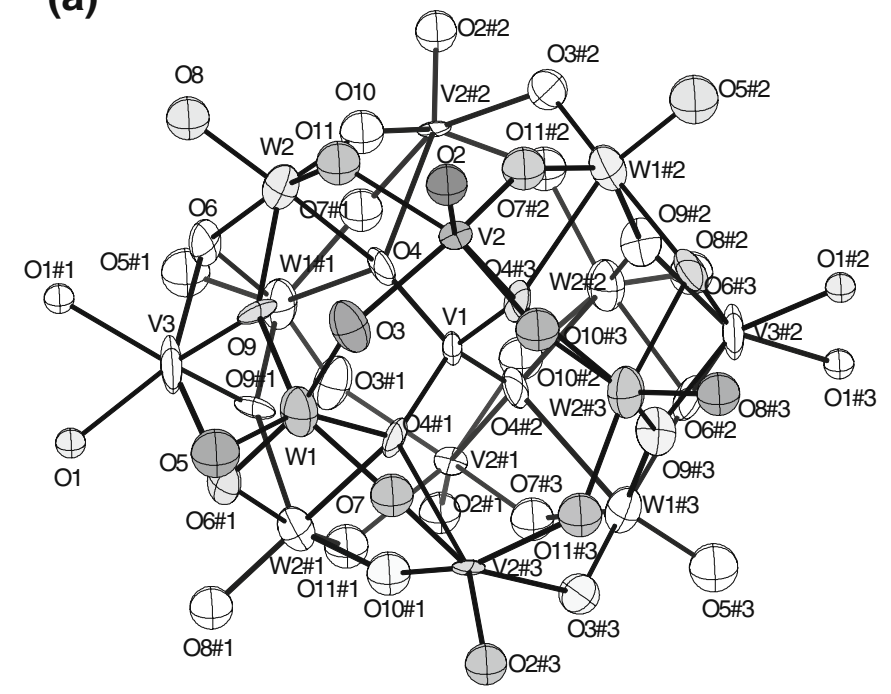

(b)

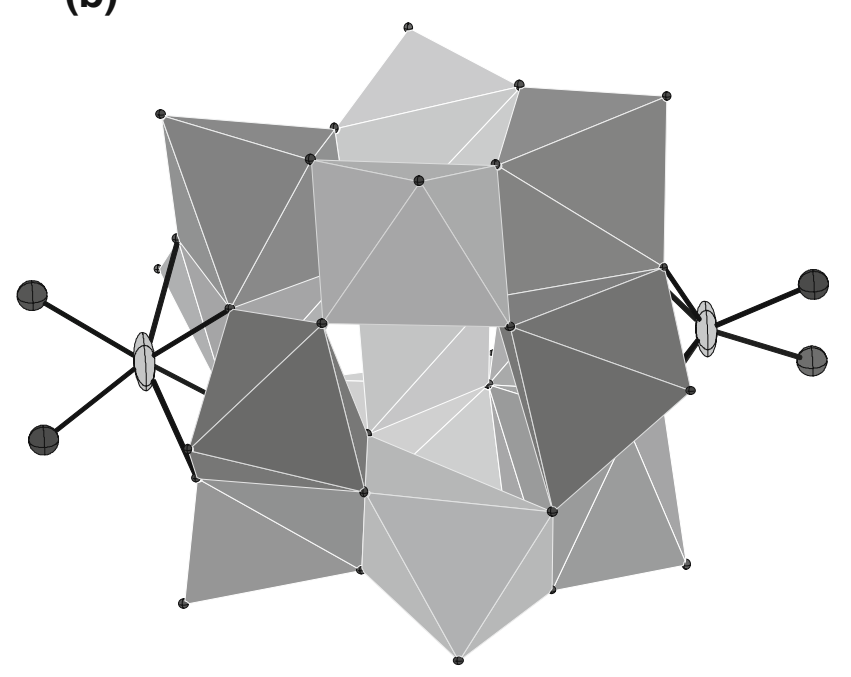

Figure 6. (a) Thermal ellipsoid plot of $\left[\left(\mathrm{V}^{\mathrm{V}} \mathrm{O}_{4}\right) \mathrm{W}_{8}^{\mathrm{VI}} \mathrm{V}_{4}^{\mathrm{IV}} \mathrm{O}_{36}\left(\mathrm{~V}^{\mathrm{IV}} \mathrm{O}\right)_{2}\right]^{7-}$. (b) Polyhedral representation of $\left[\left(\mathrm{V}^{\mathrm{V}} \mathrm{O}_{4}\right) \mathrm{W}_{8}^{\mathrm{VI}} \mathrm{V}_{4}^{\mathrm{IV}} \mathrm{O}_{36}\left(\mathrm{~V}^{\mathrm{IV}} \mathrm{O}\right)_{2}\right]^{7-}$ with capping $\{\mathrm{VO}\}^{2+}$ units in thermal ellipsoid representation.

its linking propensity towards lanthanide cation. ${ }^{15}$ In fact, this cluster anion has been used as a potential building unit in constructing coordination polymer using metal-organic complexes as linkers. ${ }^{21}$ We have utilized organic free linker, aqua-lanthanide complex $\left[\mathrm{Ln}^{\mathrm{III}}\left(\mathrm{H}_{2} \mathrm{O}\right)_{\mathrm{n}}\right]^{3+}$ and synthesized three new compounds $\left[\left\{\mathrm{Ln}\left(\mathrm{H}_{2} \mathrm{O}\right)_{6}\right\}_{2} \mathrm{As}_{8} \mathrm{~V}_{14} \mathrm{O}_{42}\left(\mathrm{SO}_{3}\right)\right] \cdot 8 \mathrm{H}_{2} \mathrm{O}, \mathrm{Ln}=\mathrm{La}^{3+}(\mathbf{5})$, $\mathrm{Sm}^{3+}(\mathbf{6})$, and $\mathrm{Ce}^{3+}(\mathbf{7})$ starting from an ammonium salt of the same cluster anion, $\left(\mathrm{NH}_{4}\right)_{6}\left[\mathrm{As}_{8} \mathrm{~V}_{14} \mathrm{O}_{42}\left(\mathrm{SO}_{3}\right)\right] .{ }^{22}$ Even though the reaction (equation 2) to obtain these compounds looks very simple, the mixing of both reactants in an aqueous medium invariably results in the immediate formation of brown precipitate, which can not be characterized unambiguously by single crystal $\mathrm{X}$-ray structure determination.

$$
\begin{aligned}
& {\left[\mathrm{NH}_{4}\right]_{6}\left[\mathrm{As}_{8} \mathrm{~V}_{14} \mathrm{O}_{42}\left(\mathrm{SO}_{3}\right)\right]+2 \mathrm{Ln}\left(\mathrm{NO}_{3}\right)_{3}} \\
& \stackrel{\mathrm{H}_{2} \mathrm{O}}{\longrightarrow}\left[\left\{\mathrm{Ln}\left(\mathrm{H}_{2} \mathrm{O}\right)_{6}\right\}_{2} \mathrm{As}_{8} \mathrm{~V}_{14} \mathrm{O}_{42}\left(\mathrm{SO}_{3}\right)\right] \\
& +6 \mathrm{NH}_{4} \mathrm{NO}_{3},
\end{aligned}
$$

where $\mathrm{Ln}=\mathrm{La}^{3+}(\mathbf{5}), \mathrm{Sm}^{3+}(\mathbf{6})$ and $\mathrm{Ce}^{3+}(\mathbf{7})$.

We, thus, performed the relevant synthesis using slow mixing technique as described below (scheme 1).

Two branches of the above shown set-up were separated by a G4 crucible bead. The dissolved reactant components in water were taken in two branches to mix slowly and single crystals, suitable for X-ray structure determination, were formed on the side wall of the set-

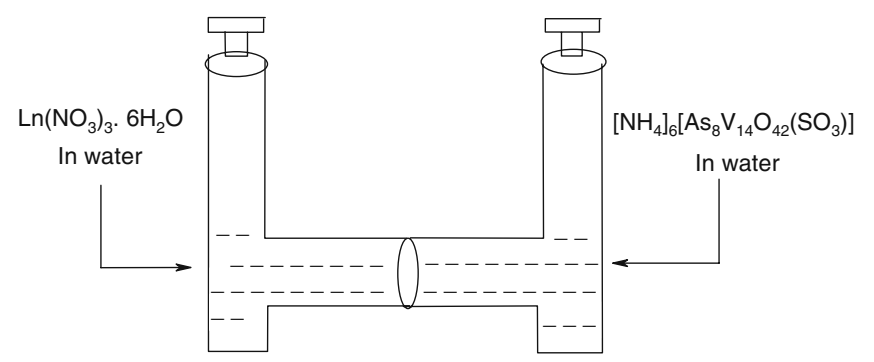

Scheme 1. Schematic representation of a set-up for the synthesis of $\left[\left\{\mathrm{Ln}\left(\mathrm{H}_{2} \mathrm{O}\right)_{6}\right\}_{2} \mathrm{As}_{8} \mathrm{~V}_{14} \mathrm{O}_{42}\left(\mathrm{SO}_{3}\right)\right] \cdot 8 \mathrm{H}_{2} \mathrm{O}$ as single crystals.

up. These crystals were collected and washed with cold water dried at room temperature.

In the crystal structures, the basic building block for the compounds 5-7 is $\left[\mathrm{As}_{8} \mathrm{~V}_{14} \mathrm{O}_{42}\left(\mathrm{SO}_{3}\right)\right]^{6-}$. The relevant asymmetric unit contains seven vanadium atoms, four arsenic atoms, a half of the disordered $\mathrm{SO}_{3}^{2-}$ molecule (with half occupancy of both sulfur and oxygen atoms), a $\left[\mathrm{Ln}\left(\mathrm{H}_{2} \mathrm{O}\right)_{6}\right]^{3+}$ ion attached to the cluster anion by coordinate covalent bond and four crystal water molecules. Accordingly, compounds 5-7 are described by a general formula $\left[\left\{\mathrm{Ln}\left(\mathrm{H}_{2} \mathrm{O}\right)_{6}\right\}_{2} \mathrm{As}_{8} \mathrm{~V}_{14} \mathrm{O}_{42}\left(\mathrm{SO}_{3}\right)\right] \cdot 8 \mathrm{H}_{2} \mathrm{O}$. The molecular structure of compound $\mathbf{1}$ is shown in figure 7 . The cluster anion $\left[\mathrm{As}_{8} \mathrm{~V}_{14} \mathrm{O}_{42}\left(\mathrm{SO}_{3}\right)\right]^{6-}$ consists of 14 distorted $\left\{\mathrm{VO}_{5}\right\}$ square pyramids and eight $\left\{\mathrm{AsO}_{3}\right\}$ triangular groups, with a disordered $\mathrm{SO}_{3}^{2-}$ anion at the center of 


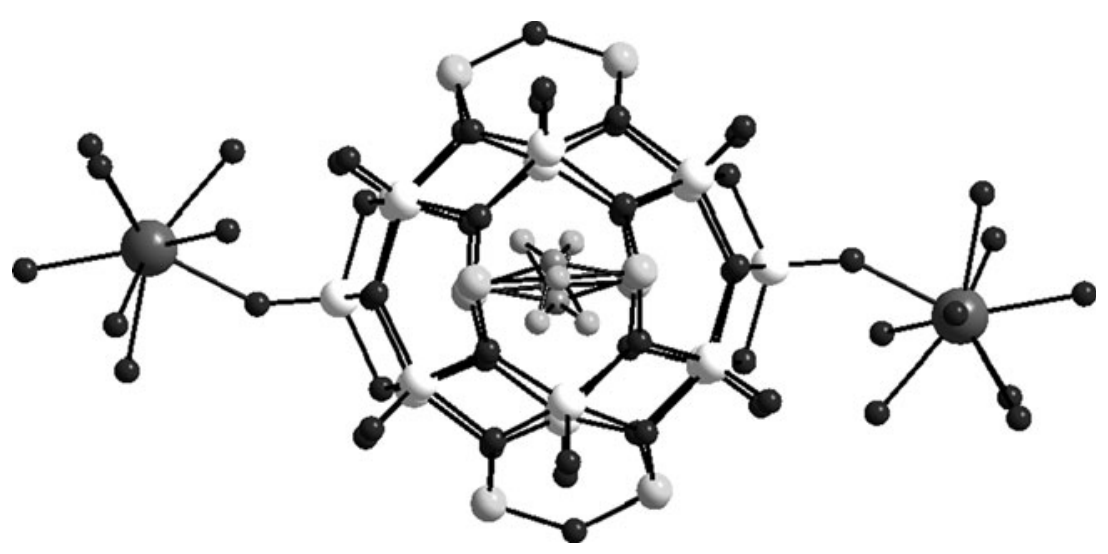

Figure 7. The molecular structure of $\left[\left\{\mathrm{La}\left(\mathrm{H}_{2} \mathrm{O}\right)_{6}\right\}_{2} \mathrm{As}_{8} \mathrm{~V}_{14} \mathrm{O}_{42}\left(\mathrm{SO}_{3}\right)\right]$ in compound 5 .
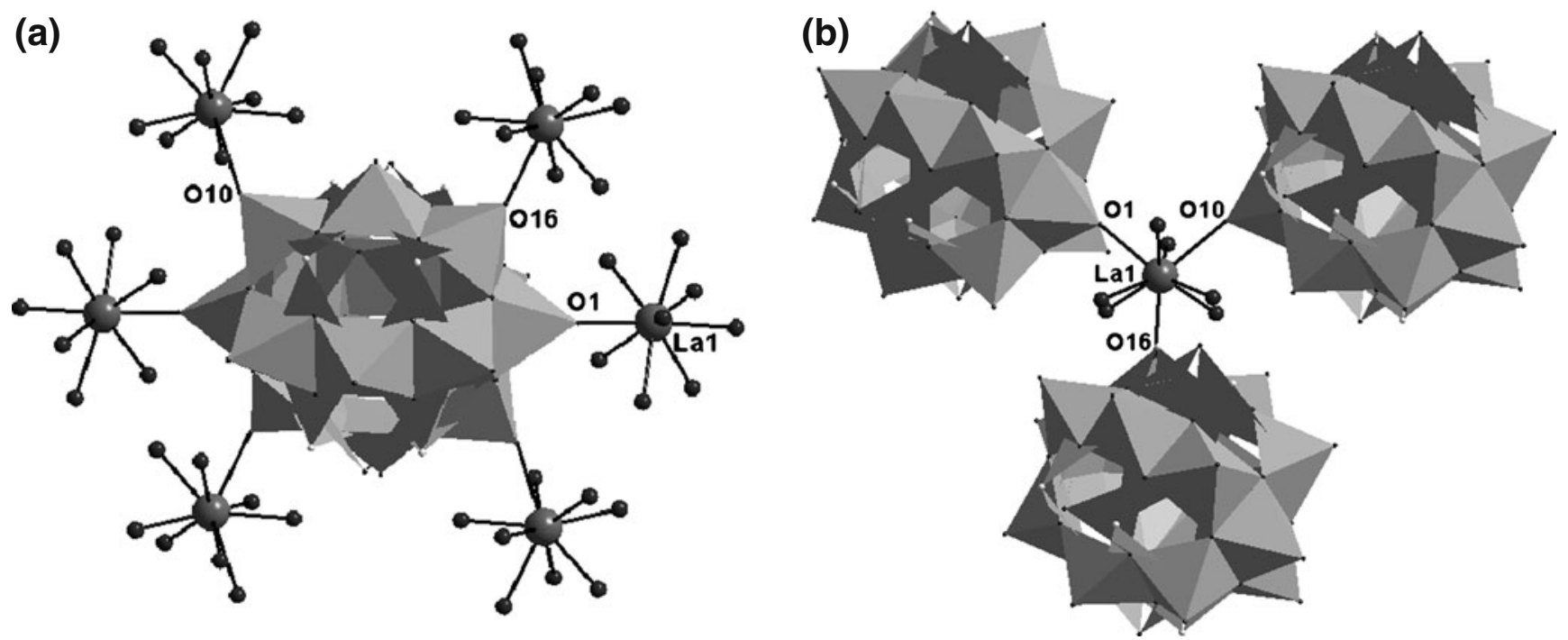

Figure 8. (a) The coordination environment of a POV cluster anion, $\left[\mathrm{As}_{8} \mathrm{~V}_{14} \mathrm{O}_{42}\left(\mathrm{SO}_{3}\right)\right]^{6-}$ with its surrounding lanthanumaqua complex cations in compound 5. (b) The coordination environment of a lanthanum cation with its surrounding POM clusters in compound $\mathbf{5}$.

the cluster anion resulting in the overall charge of the sulfite encapsulated cluster -6 . A handle-like $\left\{\mathrm{As}_{2} \mathrm{O}_{5}\right\}$ moiety is formed from two $\left\{\mathrm{AsO}_{3}\right\}$ triangular groups that are linked together by an oxygen bridge. The fourteen $\left\{\mathrm{VO}_{5}\right\}$ square pyramids, that are connected by edge sharing, are further linked to $\left\{\mathrm{As}_{2} \mathrm{O}_{5}\right\}$ units by sharing oxygen atoms resulting in a sphere-like structure with an approximate $\mathrm{D}_{2 \mathrm{~d}}$ symmetry. In compounds 5-7, all of the $\left\{\mathrm{VO}_{5}\right\}$ square pyramids on respective $\left\{\mathrm{V}_{14}\right\}$ clusters have typical geometries with apical $\mathrm{V}=$ $\mathrm{O}$ terminal bond distances and basal $\mathrm{V}-\mathrm{O}$ (in which oxygen is bridging type) bond distances 1.598(5) $\AA$ 1.641(5) and 1.918(4)-1.998(4) A respectively. In the crystal structures, each $\left\{\mathrm{V}_{14}\right\}$ cluster is coordinated to its six surrounding lanthanide ions $\left(\mathrm{Ln}^{3+}\right)$ through terminal oxygen atoms of the $\left\{\mathrm{V}_{14}\right\}$ cluster as shown in figure 8a. Similarly, each $\mathrm{Ln}^{3+}$ ion coordinated to three $\left\{\mathrm{V}_{14}\right\}$ cluster anions (figure 8b); the remaining coordination sites of the lanthanide ions are filled by six water molecules with suitable bond lengths. Thus in the crystal structure, each $\mathrm{La}^{3+}$ ion (that has coordination number of nine) attains mono-capped square-antiprism geometry. The coordination of lanthanum ions to the $\left\{\mathrm{V}_{14}\right\}$ cluster anions extends through out the crystal and result in a new type of two-dimensional (2D) network structure as shown in figure 9. As shown in the network (figures 8a and 9), each $\left\{\mathrm{V}_{14}\right\}$ cluster anion $\left\{\mathrm{As}_{8} \mathrm{~V}_{14} \mathrm{O}_{42}\left(\mathrm{SO}_{3}\right)\right\}^{6-}$ acts as hexadentate ligand and 


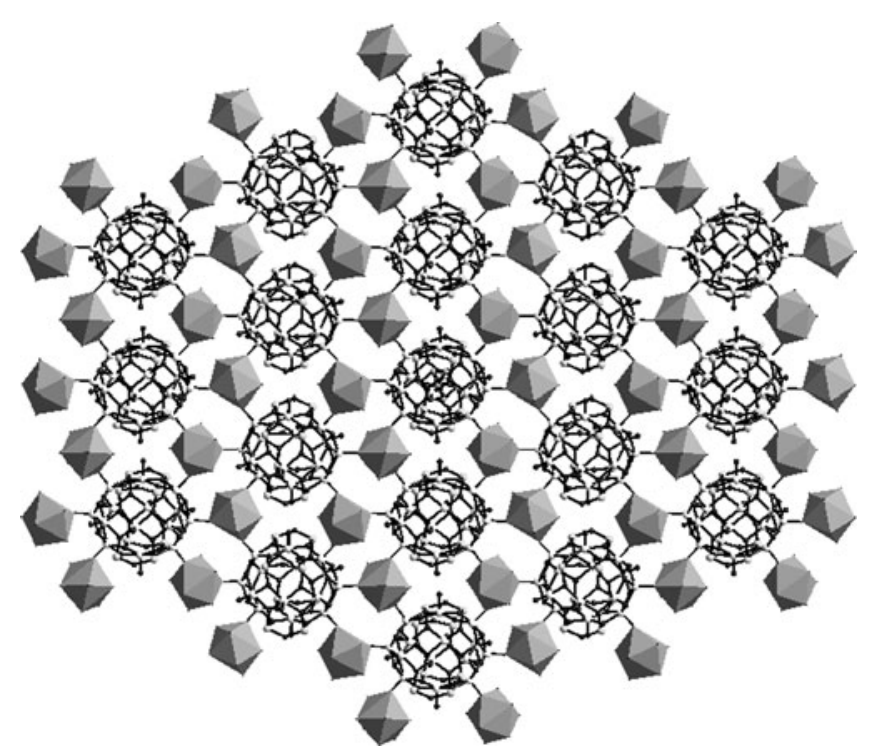

Figure 9. The two-dimensional (2D) layered structure of $\left[\left\{\mathrm{La}\left(\mathrm{H}_{2} \mathrm{O}\right)_{6}\right\}_{2} \mathrm{As}_{8} \mathrm{~V}_{14} \mathrm{O}_{42}\left(\mathrm{SO}_{3}\right)\right]$ in compound 5. Cluster anions are shown in ball-and-stick model and the lanthanumaqua complexes are shown in polyhedral representation.

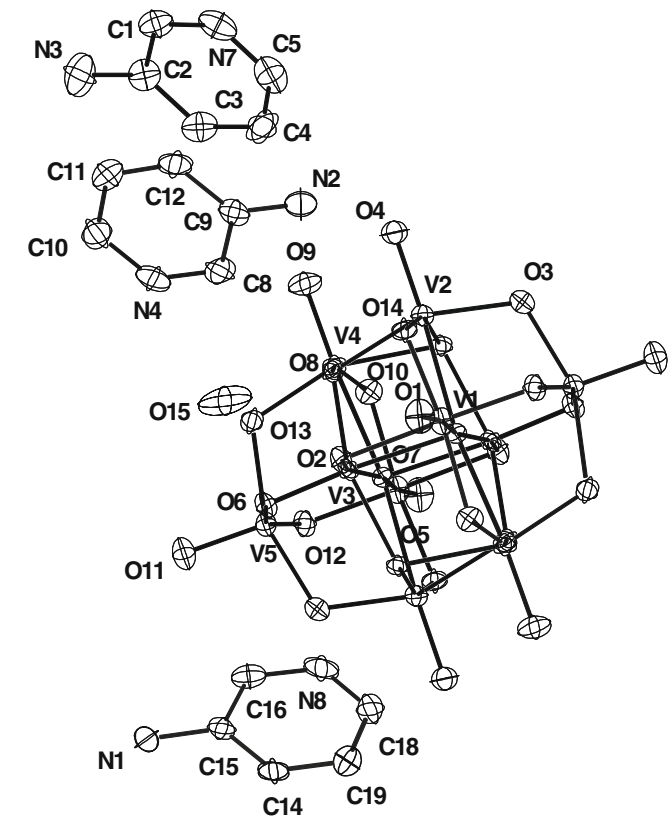

Figure 10. The thermal ellipsoidal plot (50\% probability) of compound [3-ampH $]_{6}\left[\mathrm{~V}_{10} \mathrm{O}_{28}\right] \cdot 2 \mathrm{H}_{2} \mathrm{O}(\mathbf{8})$. Three (instead of six) aminopyridinium cations are shown.
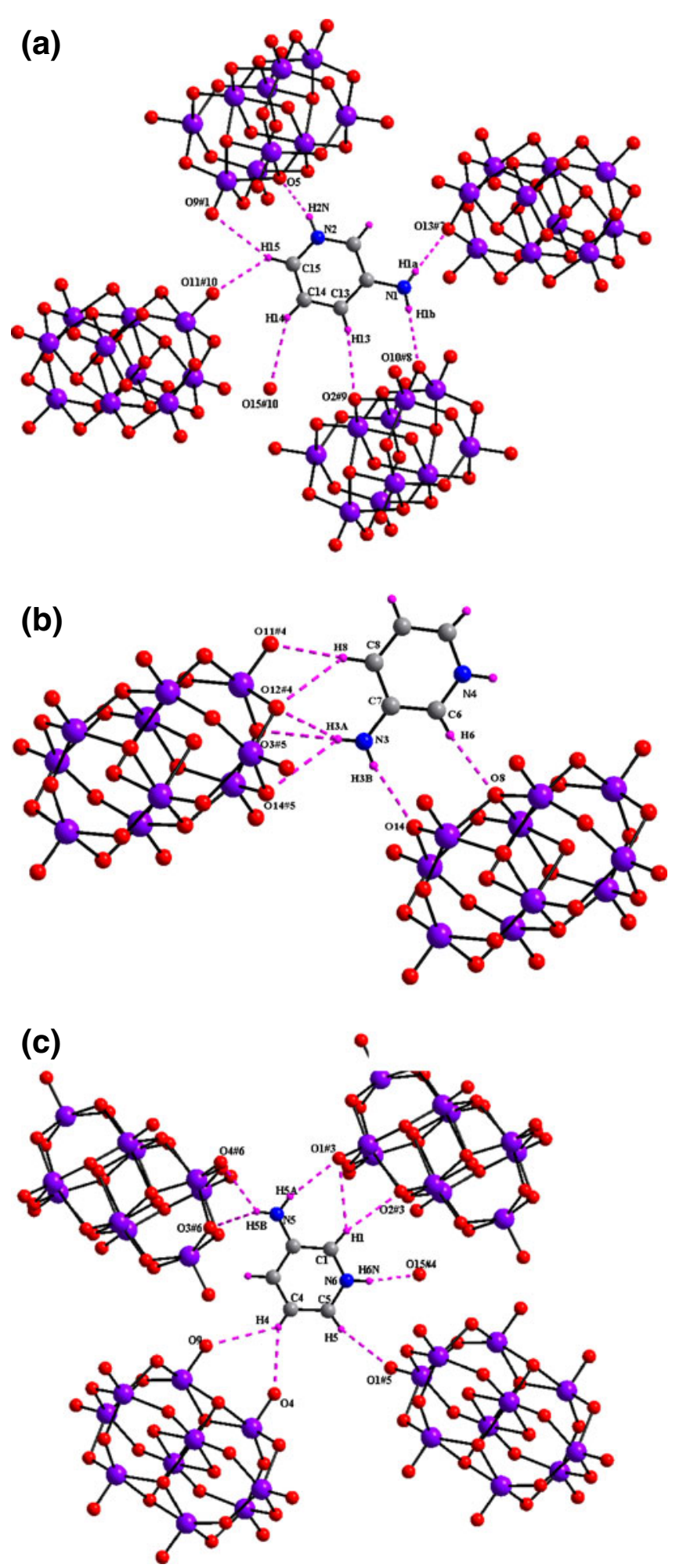

Figure 11. Hydrogen bonding situation around three crystallographically independent organic cation found in the asymmetric unit of compound $\mathbf{8}$. Colour code: V, blue violet; $\mathrm{O}$, red; $\mathrm{C}$, gray; $\mathrm{N}$, blue; hydrogen bonds are shown in purple dotted lines. 


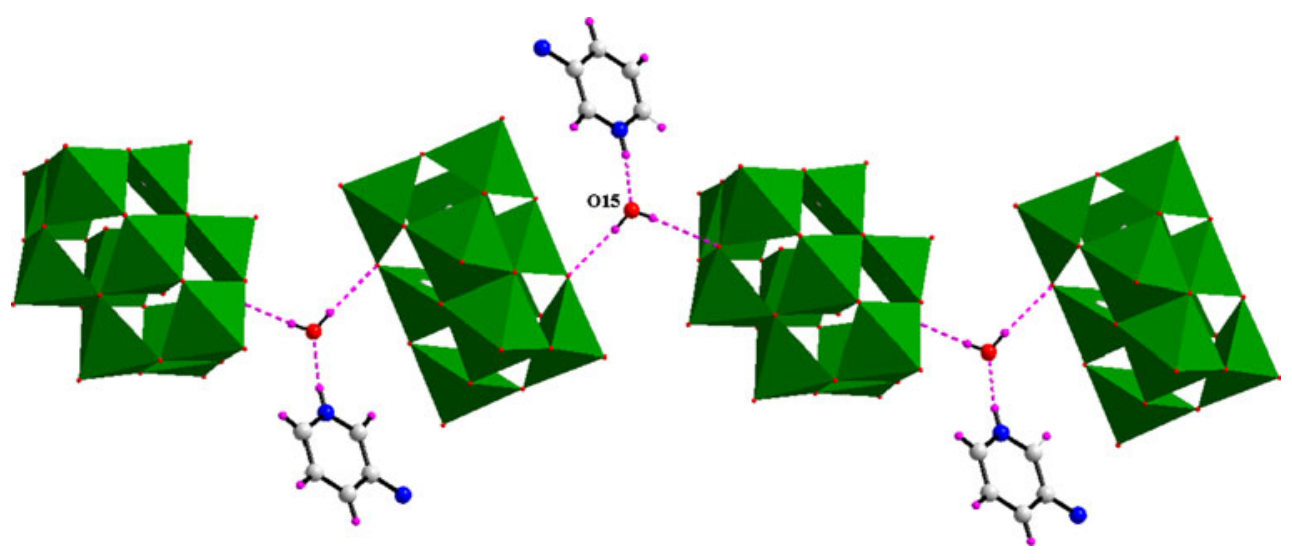

Figure 12. Hydrogen bonding situation around lattice water molecule. The isopolyanion is shown in green polyhedral representation.

hence coordinating six surrounding lanthanum complex ions. To our knowledge, this extended system of polymeric polyoxovanadates (POVs), is the first example in which the POV cluster units are linked by a lanthanide ion/lanthanide complex cation. The TGA/Mass analysis of this system shows that the structural decomposition temperature of this new class of coordination polymers (compounds 5-7) has been elevated significantly, compared with that of the discrete starting precursor compound, $\left[\mathrm{NH}_{4}\right]_{6}\left[\mathrm{As}_{8} \mathrm{~V}_{14} \mathrm{O}_{42}\left(\mathrm{SO}_{3}\right)\right]$. We have demonstrated, how a metal oxide-based cluster cage influences the stability of an inorganic anion, when it is encapsulated in the cavity of that cluster anion. ${ }^{15}$

So far, we have discussed compounds 1-7, that have extended structures based on POM cluster anions as building units and these are already reported elsewhere. ${ }^{10-15}$ Now we would describe a new system of a known POV cluster anion, namely, [3-ampH $]_{6}$ $\left[\mathrm{V}_{10} \mathrm{O}_{28}\right] \cdot 2 \mathrm{H}_{2} \mathrm{O}(\mathbf{8})$. The decavanadate containing compound $\mathbf{8}$ has been synthesized from a low $\mathrm{pH}$ aqueous solution of sodium meta-vanadate, zinc nitrate and 3-Amino pyridine (3-amp). We could not isolate compound 8 without the addition of $\mathrm{Zn}\left(\mathrm{NO}_{3}\right)_{2} \cdot 5 \mathrm{H}_{2} \mathrm{O}$ in the relevant synthesis. The role of zinc nitrate in this synthesis is not clear to us. At the low $\mathrm{pH}$, the decavanadate cluster anion $\left[\mathrm{V}_{10} \mathrm{O}_{28}\right]^{6-}$, formed from $\left[\mathrm{VO}_{3}\right]^{-}$(eq. 3), is isolated as compound 8 with 3aminopyridinium cation which is formed by protonation of 3-aminopyridine (eq. 4) at low pH of 2.

$$
\begin{gathered}
10\left[\mathrm{VO}_{3}\right]^{-}+4 \mathrm{H}^{+} \rightarrow\left[\mathrm{V}_{10} \mathrm{O}_{28}\right]^{6-}+2 \mathrm{H}_{2} \mathrm{O} \\
3-\mathrm{amp}+\mathrm{H}^{+} \rightarrow[3-\mathrm{ampH}]^{+}
\end{gathered}
$$

The IR band at $968 \mathrm{~cm}^{-1}$ is ascribed to $v(\mathrm{~V}=\mathrm{O})$ and bands at 885 and $829 \mathrm{~cm}^{-1}$ can be assigned to
$v(\mathrm{~V}-\mathrm{O}-\mathrm{V})$ mode. 3-aminopyridine exhibits its characteristics peaks in the range of $1620-1200 \mathrm{~cm}^{-1}$ in the IR spectrum.

The crystal structure of $[3-a m p H]_{6}\left[\mathrm{~V}_{10} \mathrm{O}_{28}\right] \cdot 2 \mathrm{H}_{2} \mathrm{O}$ (8) shows the abundance of $\left[\mathrm{V}_{10} \mathrm{O}_{28}\right]^{6-}$, six protonated 3-aminopyridine and two lattice water molecules per formula unit. The thermal ellipsoidal plot of compound 8 is shown in figure 10 . The isopolyanion $\left[\mathrm{V}_{10} \mathrm{O}_{28}\right]^{6-}$ is formed by ten $\left\{\mathrm{VO}_{6}\right\}$ octahedra connected with each other via edge-sharing oxygen atoms. The oxygen atoms present in this POV cluster anion are of three kinds: terminal oxygen (Ot), bridging oxygen $(\mathrm{Ob})$ and central oxygen (Oc). The crystallographic details of compound $\mathbf{8}$ are summarized in table S1. The selected bond distances and angles in the crystal structure of compound $\mathbf{8}$ is presented in table $\mathbf{S} 2$. In the crystal structure, there is an extensive hydrogen bonding interactions between the cluster anion and surrounding 3-aminopyridinium cation. There are three crystallographically independent organic cation (3-aminopyridinium) in the asymmetric unit and each of them are involved in hydrogen bonding interactions as shown in figure 11. There is one lattice water molecule in the asymmetric unit (thereby two water molecules per formula unit of compound 8). This water molecule is also involved in an extensive hydrogen bonding intraction as shown in figure 12 . In the crystal, the lattice water molecule is hydrogen bonded to two adjacent isopolyanions and one 3-aminopyridinium cation. The hydrogen bonding parameters are described in table S3. The combination of these $\mathrm{C}-\mathrm{H} \cdots \mathrm{O}$ / $\mathrm{O}-\mathrm{H} \cdots \mathrm{O} / \mathrm{N}-\mathrm{H} \cdots \mathrm{O}$ hydrogen bonds leads to an intricate three-dimensional hydrogen bonding supramolecular network as shown in figure 13. It is worth mentioning that 2-aminopyridinium salt analogue of the same decavanadate cluster $[2-\mathrm{ampH}]_{6}\left[\mathrm{~V}_{10} \mathrm{O}_{28}\right] \cdot 2 \mathrm{H}_{2} \mathrm{O}$ 


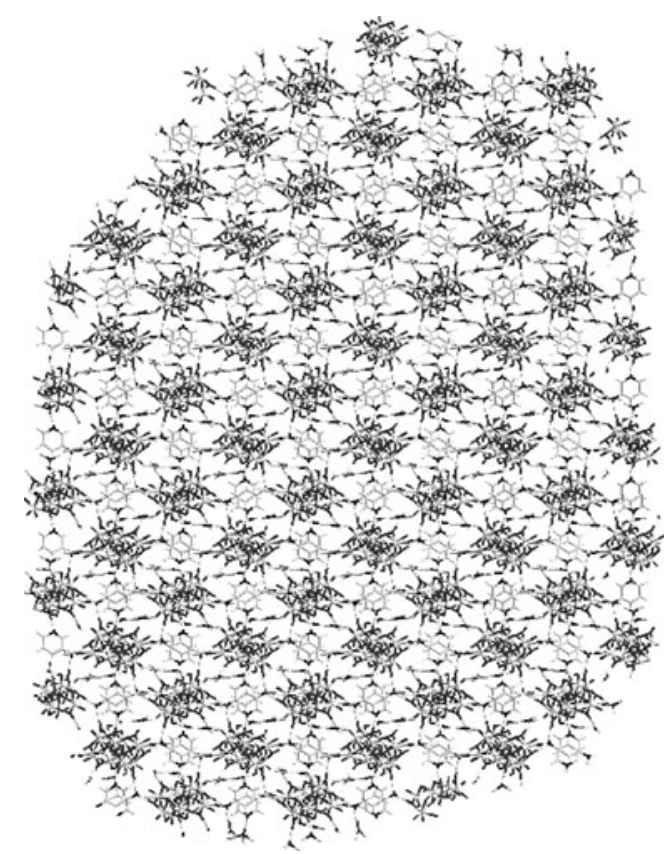

Figure 13. An intricate hydrogen bonding network observed in the crystal structure of compound $\mathbf{8}$.

is reported, ${ }^{23}$ that was characterized by a different supramolecular structure and a different space group.

\section{Conclusion}

We have demonstrated that a versatile heteropolyanion $\left[\mathrm{Al}(\mathrm{OH})_{6} \mathrm{Mo}_{6} \mathrm{O}_{18}\right]^{3-}$ can be used as a welldefined building block for the generation of multidimensional metal-oxide based architectures (compounds 1-3). We have described a one-dimensional heteropoly tungstovanadatecoordination polymer $\left(\mathrm{NH}_{4}\right)_{4.68}\left[\left(\mathrm{~V}^{\mathrm{V}} \mathrm{O}_{4}\right) \mathrm{W}_{8}^{\mathrm{VI}} \mathrm{M}_{4} \mathrm{O}_{36}\left(\mathrm{~V}^{\mathrm{IV}} \mathrm{O}\right)_{2}\right] \cdot 12 \quad \mathrm{H}_{2} \mathrm{O} \quad(\mathrm{M}=$ $\left.0.71 \mathrm{~V}^{\mathrm{IV}}+0.29 \mathrm{~W}^{\mathrm{VI}}\right)(4)$, which was a first example of a coordination polymer based on a tungstovanadate Keggin unit. We have narrated a new class of metaloxide based organic free materials based on lanthanide linked sulfite encapsulated polyoxovanadate clusters (compounds 5-7). Compounds 1-7 are coordination polymers based on coordinate-covalent bonds and are reported previously. Finally, we have described a new POV system $[3-\mathrm{ampH}]_{6}\left[\mathrm{~V}_{10} \mathrm{O}_{28}\right] \cdot 2 \mathrm{H}_{2} \mathrm{O}(\mathbf{8})$ that has discrete molecular structure but is characterized by an intricate three-dimensional supramolecular structure. Moreover, amino-pyrimidine derivatives (compound $\mathbf{8}$ in the present context) are supposed to be biologically important compounds because they occur in nature as components of nucleic acids. ${ }^{24}$ It has been shown that some amino-pyrimidine compounds have potential to act as antifolate drugs. ${ }^{25}$ Thus, compound $\mathbf{8}$ is not only important on materials aspect but also important as far as model drug related compounds are concerned.

\section{Supplementary information}

The tables S1, S2 and S3 are given as supplementary information (see www.ias.ac.in/chemsci).

\section{Acknowledgements}

We thank the Department of Science and Technology (DST), Government of India, for financial support (Project No. SR/SI/IC-23/2007). The National $\mathrm{X}$-Ray Diffractometer facility at the University of Hyderabad under the Department of Science and Technology, Government of India, is gratefully acknowledged. ASR thanks Council of Scientific and Industrial Research (CSIR), Government of India, for a fellowship. We also acknowledge Centre for Nanotechnology, University of Hyderabad, for infrastructure facility.

\section{References}

1. Pope M T 1983 Heteropoly and isopoly oxometalates, (Springer-Verlag, Berlin); Izumi Y, Urabe K and Onaka M 1992 Zeolite, clay and heteropoly acid in organic reactions (Tokyo); Pope M T and Müller A 1991 Angew. Chem., Int. Ed. Engl. 30 34; Okumara T Mizuno N and Misono M 1996 Adv. Catal. 41 113; Hill C L and Prosser-McCartha C M 1995 Coord. Chem. Rev. 143 407; Hill C L (ed.) 1998 Chem. Rev. 98 1, special edition on polyoxometalates; Arumuganathan T, Rao A S, Vijaykumar T and Das S K 2008 J. Chem. Sci. 12095

2. Shivaiah V, Arumuganathan T and Das S K 2004 Inorg. Chem. Commun. 7 367; Müller A, Peters F, Pope M T and Gatteschi D 1998 Chem. Rev. 98239

3. Perloff A, 1970 Inorg. Chem. 9 2228; Rosu C and Dickman M H 1999 Acta Crystallogr. Sect. C. 5511

4. Sadakane M, Dickman M H and Pope M T 2000 Angew. Chem., Int. Ed. 39 2914; Galán-Mascarós J R, GimenezSaiz C, Triki S, Gómez-García C J, Coronado E and Ouahab L 1995 Angew. Chem., Int. Ed. Engl. 34 1460; Müller A, Koop M, Schiffels P and Bögge H 1997 Chem. Commun. 1715

5. Gimenez-Saiz C, Galán-Mascarós J R, Triki S, Coronado E and Ouahab L 1995 Inorg. Chem. 34524

6. Molchanov V N, Tatjanina I V, Torchenkova E A and Kazansky L P 1981 J. Chem. Soc., Chem. Commun. 93

7. Yamase T and Naruke H 1991 J. Chem. Soc., Dalton Trans. 285

8. Zhang S-W, Wei Y-G, Yu Q, Shao M-C and Tang Y-Q 1997 J. Am. Chem. Soc. 119 6440; Liu G, Wei Y-G, Yu Q, Liu Q and Zhang S-W 1999 Inorg. Chem. Commun. 2434

9. Shivaiah V and Das S K 2005 Inorg. Chem. 448846 
10. Shivaiah V, Reddy P V N, Cronin L and Das S K 2002 J. Chem. Soc., Dalton Trans. 443781

11. Shivaiah V, Nagaraju M and Das S K 2003 Inorg. Chem. 426604

12. ManiKumari S, Shivaiah V and Das S K 2002 Inorg. Chem. 416953

13. Shivaiah V and Das S K 2005 J. Chem. Sci. 117227

14. Shivaiah V, Hajeebu S and Das S K 2002 Inorg. Chem. Commun. 5996

15. Arumuganatham T and Das S K 2009 Inorg. Chem. 48 496

16. Sheldrick G M 1998 Software for the CCD Detector System (Bruker analytical X-ray systems Inc., Madison, WI)

17. Sheldrick G M 1996 SADABS, A program for absorption correction with the Siemens SMART area-detector system (University of Göttingen, Germany)

18. Sheldrick G M 1997 SHELXS-97, A program for solution of crystal structures (University of Göttingen, Germany)

19. Sheldrick G M 1997 SHELXL-97, A program for solution of crystal structures (University of Göttingen, Germany)

20. Anderson J S 1937 Nature (London) 140850

21. Zhou G, Xu Y, Guo C and Zheng X 2007 Inorg. Chem. Commun. 10 849; Zheng S-T, Zhang J, Xu J-Q and Yang G-Y 2005 J. Solid State Chem. 178 3740; Zheng S-T, Zhang J and Yang G-Y 2005 J. Mol. Struct. 752 25; Qi Y, Li Y, Wang E, Jin H, Zhang Z, Wang X and Chang
S 2007 Inorg. Chim. Acta 360 1841; Cui X-B, Sun Y-Q and Yang G-Y 2003 Inorg. Chem. Commun. 6 259; Zheng S-T, Zhang J, Xu J-Q and Yang G-Y 2005 J. Solid State Chem. 178 3695; Cui X-B, Xu J Q, Li Y, Sun Y H and Yang G Y 2004 Eur. J. Inorg. Chem. 1051; Zheng S-T, Zhang J, and Yang G-Y 2005 Inorg. Chem. 44 2426

22. Müller A and Döring J 1991 Z. Anorg. Allg. Chem. 595 251

23. Gong Y, Hu C, Li H, Tang W, Huang K and Hou W 2006 J. Mol. Struct. $\mathbf{7 8 4} 228$

24. Hemamalini M, Muthiah P T, Butcher R J and Lynch D E 2006 Inorg. Chem. Commun. 9 1155; Brown D J and Mason S F 1962 The pyrimidines (New York: Interscience Publishers John Wiley and Sons); Brouillette C B, Chang C T and Mertes M P 1979 J. Med. Chem. 22 1541; Dlercq E D, Descamps J, Huang G and Torrence P 1978 Mol. Pharmacol. 14 422; Danenberg P V 1977 Biochim. Biophys. Acta 497 7392; Silva A D D, Machado A S, Tempete C and Robert-Gero M 1994 Eur. J. Med. Chem. Chim. Ther. 29 1149; Sondhi S M, Johar M, Rajvanshi S, Dastidar S G, Shukla R, Raghubir R and Lown J W 2001 Aust. J. Chem. 54 169; Kidwai M, Saxena S, Rastogi S and Venkataramanan R 2003 Curr. Med. Chem. Ant-Infective Agents 2269

25. Huang S, Li R, Connolly P J, Xu G, Gaul M D, Emanuel S L, Lamontagne K R and Greenberger L M 2006 Bioorg. Med. Chem. Lett. 166063 